\title{
GRADA KILOMBA E ROSANA PAULINO: DUAS PÉROLAS NEGRAS ATLÂNTICAS À BEIRA DO TEJO - LEMBRANÇAS DO OLHAR, DO ESCUTAR E DO OBSERVAR
}

\author{
Luzia Gomes Ferreira \\ FAV/ICA/UFPA
}

\section{Resumo}

Neste artigo de percurso expositivo, apresento as minhas lembranças de visitante-poeta nas exposições «The Most Beautiful Language» e «Secrets to Tell» de Grada Kilomba, e «Atlântico Vermelho» de Rosana Paulino, ambas realizadas na cidade de Lisboa em outubro de 2017. Assim como, teço reflexões problematizadoras sobre exposições, arte, racismo e lugar de enunciação artística. Regresso a Lisboa em pensamento, imagens, palavras, água e som para afirmar que representatividade negra importa nas duas margens atlânticas. E sigo almejando que no Brasil e em Portugal num futuro bem próximo, exposições como a da Grada Kilomba e da Rosana Paulino, sejam constantes e não, raras pérolas negras.

\section{Palavras-chave:}

Atlântico; Exposições de Arte; Grada Kilomba; Rosana Paulino; Tejo.

\footnotetext{
"Tente usar a roupa que eu estou usando ${ }^{1}$ Tente esquecer em que ano estamos Arranje algum sangue, escreva num pano Pérola Negra, te amo, te amo" (Luiz Melodia)
}

\section{TEZ NEGRA NO INTERIOR EXTERNO DA ARTE BRANCA}

Sou museóloga de formação, professora do curso de Museologia, lotada na Faculdade de Artes Visuais (FAV) do Instituto de Ciências da Arte (ICA) da Universidade Federal do Pará (UFPA) e ministro atividades curriculares do Núcleo de Teoria Museológica, ainda que, enquanto museóloga, compreenda a indissociabilidade entre teoria e prática/prática e teoria na Museologia.

Como bem nos lembra Nicholas Mirzoeff: “[...]'teoria' não são só palavras numa página, mas também

\section{Abstract}

In this expositive article I present my memories as a visitor-poet at the exhibitions "The Most Beautiful Language" and "Secrets to Tell" by Grada Kilomba and "Atlântico Vermelho" by Rosana Paulino, both held in the city of Lisbon in October 2017. As well as I have problematizing reflections about expositions, art, racism and place of artistic enunciation. I return to Lisbon in thought, images, words, water and sound to affirm that black representation matters on the two Atlantic Margins. And I am still aiming that in the near future expositions such as Grada Kilomba's and Rosana Paulino's are constant in Brazil and Portugal and not rare black pearls.

Keywords:

Atlantic; Art Expositions; Grada Kilomba; Rosana Paulino; Tejo.

coisas que se fazem. (...) Abrir a teoria não é uma posição anti-teoria, mas é contra o elitismo como um fim em si mesmo. (...)Abrir a teoria é uma injunção para ser tão inclusivo quanto possível." (MIRZOEFF, 2018). Nesse sentido, concebo as exposições como a materialização simbiótica da teoria e da prática sem hierarquização. Contudo, não romantizo as exposições, pois tudo que é da ordem da construção humana nas sociedades ocidentais estruturadas pelas hierarquizações de raça, gênero, classe, geração, nacionalidade e tantas outras formas de estabelecer opressões não tem neutralidade; é passível de falhas e equívocos. Nos processos e projetos expositivos temos historicamente as presenças de alguns/ algumas e as ausências de tantos/as outros/as.

Tampouco considero a expografia a parte mais importante das instituições museológicas, embora 
não conceba museu sem exposição. Por outro lado, não é possível desconsiderar outros espaços realizadores de exposições, como as galerias de arte, centros culturais e institutos de artes. Essas exposições também interessam-me e eu as visito.

Neste artigo não pretendo realizar um histórico das exposições nos museus nem fora deles, nem uma análise expográfica numa perspectiva museológica e nem de crítica de arte, até mesmo porque não sou crítica e nem curadora. Lançando mão da minha licença poética de poeta, almejo construir um texto sobre as minhas lembranças do olhar, do escutar, do observar e do participar de exposições como parte integrante do público. Este é um texto das minhas memórias expositivas, as quais sempre me proporcionaram viajar sem sair do lugar. Quase sempre não me vejo nas telas, nos vídeos, nas fotografias, nas instalações, nas legendas, nos textos curatoriais, na curadoria, nem no "público em geral", que na maior parte do tempo nas exposições de arte é um público específico. Por isso, relatar as minhas lembranças sobre as exposições «The Most Beautiful Language» e «Secrets to Tell» da artista portuguesa Grada Kilomba realizada na cidade de Lisboa em 2017, e «Atlântico Vermelho» da artista brasileira Rosana Paulino também ocorrida na mesma cidade, no mesmo ano e período, é uma forma de falar da importância do se ver através das duas artistas nos espaços hegemônicos das artes visuais, nos quais, quase sempre as pessoas negras são invisíveis enquanto artistas, curadoras e público.

Antes de adentrar especificamente às exposições das artistas Grada Kilomba e Rosana Paulino,é necessário tecer algumas considerações sobre arte e racismo, assim como sobre exposição de forma mais ampliada. Conforme pontua a autora Djamila Ribeiro: “[...] a arte não está descolada dos valores da cultura e tampouco é neutra. (RIBEIRO, 2018, p. 62). A escritora continua sua reflexão sobre arte: "[...] Não é possível falar de política, sociedade e arte sem falar de racismo e sexismo." (RIBEIRO, 2018, p. 78). Por mais repetitivo que seja para nós acadêmicas/os negras/os e artistas negras/os é sempre válido enfatizar que ainda hoje as artes negras (afrodiaspóricas e africanas), em muitos contextos brasileiros e internacionais, estão ausentes nas referências teóricas da História da Arte, da Filosofia da Arte, da Crítica de Arte e da Curadoria de Arte.
No tocante ao Brasil, por mais que tenhamos artistas negras e negros produzindo e tensionando as relações raciais artisticamente, bem como abordando outros temas, continuamos sendo invisibilizadas/os como parte constituinte da História da Arte Brasileira. Como o racismo é perversamente um elemento estruturante da sociedade brasileira, é evidente que o mesmo também atravessa a cadeia operatória do sistema da arte. Por isso, precisamos nominá-lo, para combatê-lo!

Quase sempre ao ser questionada sobre exposições visitadas por mim, as pessoas querem ouvir as minhas reflexões enquanto museóloga e não como parte do público. Considero isso um aspecto interessante, pois a minha formação em Museologia, aos olhos de outras pessoas me "habilita" ter uma análise técnica e conceitual da expografia como o todo, independente do tema exposto. Contudo, caras leitoras e caros leitores nem sempre estou interessada em analisar tecnicamente e conceitualmente as exposições que visito. Há momentos que apenas desejo descansar o meu olhar, ter uma experiência estética e contemplar obras que são significativas para mim. Outro fato que constantemente ocorre é das pessoas considerarem que por ser negra e refletir sobre questões raciais na minha produção e trajetória acadêmica, só desejo visitar exposições e museus que tratem dessa temática.

Curiosamente, tanto em Portugal quanto aqui no Brasil, sempre ouço que "devo" visitar o museu do Quai Branly em Paris, ainda que, particularmente, nas raras vezes que penso em conhecer "a cidade luz e do glamour ocidental", o museu que vem à minha cabeça é o "D'Orsay". Porém, não sei porque as pessoas acreditam que tenho uma vontade atlântica de conhecer Paris e, acima de tudo, que sinto um desejo incondicional de ver o "Quai Branly". Estou mais para Istambul do que para Paris e muito mais curiosa para adentrar o «Museu da Inocência», criado pelo escritor turco Ohan Pamuk após ter escrito o romance com o mesmo nome, o qual li e me fascinei pela história de amor entre Kemal e Füsun permeada pelo colecionismo, tendo o museu como espaço de materialização dessa relação amorosa. Sem falar que, ter assistido o filme "O Som de Istambul» (2005) de Fatih Akin, cineasta alemão de ascendência turca, despertou em mim o desejo de atravessar o Estreito de Bósforo, ouvindo a banda 
«Light in Babylon»². Istambul é uma cidade que é tão minha de tão distante que é de mim. Tudo isso para afirmar o seguinte: ser mulher negra é parte da minha existência, mas não é a limitação do meu ser. Nesse sentido, concordo com a reflexão da Grada Kilomba que segue abaixo:

Quero ter essa liberdade humana de ser eu. (...) Precisamos focar nas nossas competências, no modo como estamos transformando as agendas e os discursos. O que me interessa são as pessoas que dialogam comigo, não as outras vozes. Como mulheres negras, feministas que descolonizam o pensamento, precisamos aprender a focar na energia certa. (KILOMBA apud RIBEIRO, 2018, p. 109-112).

Outro ponto a ser enegrecido nesse artigo é que, como artista, penso no lugar de enunciação das/ os artistas, assim como na liberdade que qualquer artista, independente de raça, gênero, classe, geração e nacionalidade, deve ter para criar e abordar o tema que Ihe apetecer em seus trabalhos artísticos. Não acredito ser viável exigir que toda/o artista negra/o do contexto afrodiaspórico ou africano tenha uma pauta racial, descolonial com viés político. A artista Rosana Paulino ao ser entrevista pela Revista do Centro de Pesquisa e Formação (CPF) do SESC - SP, é questionada com a seguinte pergunta: "Para você a obra de arte deve necessariamente ter uma função social e política perante a realidade?" (CPF, 2017, p. 235). A artista responde:

Não, cada uma/um tem direito de seguir o caminho que melhor se adapta, que mais Ihe interessa, senão vira uma camisa de força, um gueto. Não posso impor a outras/outros minhas opções mesmo porque não tomar uma atitude política já é uma atitude política e isso tem que ser respeitado. (PAULINO, 2017, p. 235).

Pensando no meu próprio processo de escrita poética, há dias que pelas próprias pressões e opressões sociais sou levada e escrever sobre o racismo que me assola enquanto mulher negra, especialmente, quando leio nos jornais notícias como a do assassinato do adolescente Marcos Vinícius de 14 anos, morto pela polícia a caminho da escola numa operação no Complexo da Maré, no Rio de Janeiro, em junho de 2018, o que me levou a escrever o poema «é PReCiSo chOrAr!»». Foi desolador constatar como a morte desse adolescente não gerou comoção nacional e facilmente caiu no esquecimento, apenas nos afirmando que vidas negras não importam. Por outro lado, há momentos que faço uma poesia como «O COCHiLO dA IUA» para homenagear a pintora e poeta coreana Shin Saimdang, que viveu no século XVI. Ao assistir a série da Netflix «Saimdang, A Memória das Cores», fiquei arrebatada por essa artista e fui pesquisar sobre a mesma e desdobrei essa investigação em poesia. Com isso, quero dizer o seguinte: os nossos olhares sobre as produções artísticas de artistas negras e negros deve ser plural, porque nós negras e negros não somos uma massa homogênea. Porém, não penso a arte fora do campo político e nem percebo as/os artistas como seres apáticas/os ao mundo que as/os cerca. E se tratando do contexto brasileiro e não só, é preciso não esquecer as palavras do intelectual, ativista e artista Abdias do Nascimento, invisibilizado nos nossos estudos em arte e sobre arte na academia. Ele nos lembra o seguinte:

[...] sem exceção, tudo o que sobrevive ou persiste da cultura africana e do africano como pessoa, no Brasil, é a despeito da cultura ocidental europeia e dominante, do "branco" brasileiro, e da sociedade que, há quatro séculos, reina no país. Os africanos e seus descendentes, os verdadeiros edificadores da estrutura econômica nacional, são uns verdadeiros coagidos, forçados a alienar a própria identidade pela pressão social, se transformando cultural e fisicamente em brancos. (NASCIMENTO, 2017, p. 153).

Concordo com as palavras do Abdias do Nascimento. Contudo, graças a ele e a tantas/os outras/os artistas negras e negros que vieram antes de nós, podemos chegar ao século XXI mesmo com as nossas chagas abertas e afirmar que temos individualidades, subjetividades e licença poética. Evidenciar esses aspectos em nossos trabalhos artísticos, também é um ato político. Sobre individualidade Milton Santos refletiu:

A individualidade é uma conquista demorada e sofrida, formada de heranças e aquisições culturais, de atitudes aprendidas e inventadas e de formas de agir e de reagir, uma construção que, ao mesmo tempo, é social, emocional e intelectual, mas constitui um patrimônio privado, cujo valor intrínseco não muda aavaliação extrínseca, nem a valoração objetiva da pessoa, diante de outro olhar. No Brasil, onde a cidadania é, geralmente, mutilada, o caso dos negros é emblemático. Os interesses cristalizados, que produziram convicções escravocratas arraigadas, mantêm os estereótipos, que não ficam no limite do simbólico, incidindo sobre os demais aspectos das relações sociais. $\mathrm{Na}$ esfera pública, o corpo acaba por ter um peso maior do que o espírito na formação da socialidade e da sociabilidade. (SANTOS, 2000, p. 03). 
Em alguns seguimentos artísticos brasileiros, sejam dentro ou fora da academia, ainda sinto que falar de racismo é quase um tabu, um palavrão a ser evitado. Podemos falar de temas herméticos da moda acadêmica contemporânea, herdados especialmente da Europa e dos Estados Unidos. Todavia, ainda há, por parte de alguns e algumas, a resistência em trazer as discussões raciais para o âmbito das artes. Não se estranha os ínfimos números de artistas negras e negros nacionais e internacionais nas Bienais de São Paulo, por exemplo. Ter um ou no máximo cinco, não é representativo do todo, até mesmo porque as mostras das Bienais que visitei nunca contei no máximo cinco artistas brancos/as nas pontas dos dedos. Aliás, os/as brancos/as não se contam, eles e elas estão infinitamente em maior número nos eventos artísticos brasileiros e não só. Afinal de contas, apesar da arte ser feita e consumida por pessoas atravessadas pelo privilégio e desprivilégio da cor da pele, há setores que insistem em dizer que "a arte não tem cor". Não causa incômodo ser praticamente inexistente os curadores negros e as curadoras negras reconhecidos/as no cenário nacional. É normatizada a ausência de autores negros e autoras negras na literatura acadêmica no campo das artes, assim como no exercício da docência em institutos de artes nas universidades públicas brasileiras. Conforme nos lembra Fanon: "O racismo avoluma e desconfigura o rosto da cultura que o pratica. A literatura, as artes plásticas [...] quer se proponham fazer-Ihe o processo ou banalizá-lo, restituem o racismo" (FANON, 2012, p.279).

Para escrever esse artigo, parei para reler alguns textos e pesquisar outros mais atuais. Nessa busca, encontrei a Revista Selecct: Arte e Cultura Contemporânea, edição 40, Set/Out/Nov, ano 07, 2018. A revista está muito interessante e apresenta na capa um trabalho da artista negra estadunidense Nona Faustine, que faz parte da mostra Histórias Afro-Atlânticas, realizada no Museu de Arte de São Paulo Assis Chateubriand (MASP) e no Instituto Tomie Ohtake, na cidade de São Paulo, 2018. Visitei a referida exposição em julho do corrente ano. Comprei a revista porque queria ler a matéria «A História das Exposições é a Nova História da Arte?». A chamada é a seguinte:

A história das exposições vem ganhando frente em estudos da arte contemporânea. Ao mesmo tempo, exposições históricas vêm sendo remontadas, mostrando o papel que as instituições desempenham na legitimação de obras e artistas. A seguir, curadores, gestores e professores discutem se história das exposições representa a nova história da arte. (SELECT, 2018, p. 38).

Apesar da importância do tema tratado na matéria, para mim enquanto museóloga, professora e pesquisadora num curso de Museologia que funciona dentro de uma Faculdade de Artes Visuais, o que mais chamou à minha atenção ao ler a matéria é que os rostos dos/as curadores/ as, gestores/as e professores/as exibidos ao lado das suas reflexões, são todos rostos brancos. Sim, tenho o olhar treinado para esses pequenosgrandes detalhes, porque estou sempre à procura das minhas e dos meus. Nessa matéria senti falta de rostos e nomes como: Diane Lima, Fabiana Lopes, Alexandre Araújo Bispo, Renata Felinto, Hélio Menezes, por exemplo. Mais uma vez, pecase ao não trazer para a reflexão o pensamento de curadoras/es, gestoras/es e professoras/ es negras/os para o centro de um debate tão importante para quem atua no campo das artes, dos museus e da Museologia. Nesse sentido, mais uma vez, é mostrado que o pensamento teórico sobre quaisquer aspectos das artes, ainda é majoritariamente branco no cenário brasileiro. Como bem relata o artista-curador Daniel Lima:

Talvez a arte contemporânea seja a mais segregada de todas as instituições culturais, e tem de repensar como lida com as questões raciais no Brasil, em seus acervos, em suas equipes de trabalho, a própria função do museu, a própria ideia de instituição e a sua relação com a sociedade. (LIMA, 2017).

Criar exposições é uma forma de apresentar leituras de mundo e não podemos ter apenas um único ponto de vista e olhar sobre esse mundo tão grande e diverso, que não conheço em sua totalidade. Por isso, ao conceber e materializar exposições é preciso entender que: artes negras importam; artistas negras e negros importam; curadoras negras e curadores negros importam; críticas negras e críticos negros importam; historiadoras da arte negras e historiadores da arte negros importam e o pensamento negro importa. Ademais, seja no Brasil ou na Europa, é preciso se atentar para a reflexão da Daniela Labra na sua crítica intitulada «Sem Paternalismo Nem Vitimização», na Revista Select de Arte e Cultura Contemporânea (2018) sobre a Bienal de Berlim que teve curadoria da curadora sul-africana Gabi 
Ngcobo com o título We Don't Need Another Hero (Nós Não Precisamos de Outro Herói), título de uma música da Tina Tuner.

Se a Modernidade como projeto civilizatório foi falha e violenta, a fórmula de dominação cultural da cartilha eurocentrada esgotou-se há muito. Portanto, o Ocidente precisa admitir, sem paternalismos ou vitimização, sua ignorância arrogante sobre os processos históricos dos que chamam de outro identitário. Com esse recado a 10 ( Bienal de Berlim, traz ensinamentos que vão além do politicamente correto e deve ser vista com atenção na história das exposições recentes de arte contemporânea. (LABRA, 2018, p.103).

Visito exposições para ver gente a partir das coisas criadas e recriadas pelo labor hmano. A partir dessas coisas que se desdobram em diferentes materialidades e visualidades, procuro compreender a minha existência e a das minhas e dos meus semelhantes. Porque as coisas carregam em si pedaços de gente, fragmentos de pessoas que nunca se viram e que talvez nunca se verão, que existiram em tempos e espaços distintos ou que coexistiram, ou coexistem ao mesmo tempo, em pontos distantes. As coisas transportam consigo partes de gente de todo o mundo e de um só lugar do planeta que habitamos com as suas perversas e arbitrárias fronteiras concretas e imaginárias.

A partir de agora atravessarei para a outra margem do atlântico e aportarei na beira doTejo em Lisboa, mergulhando nas lembranças do meu corpo negro percorrendo as exposições da Grada Kilomba e da Rosana Paulino. Convido você, cara leitora e caro leitor para viajar comigo até a cidade de Luz Boa embalada/o ao som palavrado de uma das músicas que mais me embalou nas noites lisboetas: «Sodade». Morna que ficou para a posteridade gravada e grafada na voz da caboverdiana Cesária Évora.

Quem mostra bo es caminho longe?

Quem mostra bo es caminho longe?

Es caminho pa São Tomé

Sodade

Sodade

Sodade

Des nha terra, São Nicolau

Si bo screve m',

$\mathrm{M}^{\prime}$ ta screve bo

Si bo squece $\mathrm{m}^{\prime}$

$\mathrm{M}^{\prime}$ ta squece bo

Até dia qui bo volta

Sodade

Sodade
Sodade

Des nha terra, São Nicolau

(Amândio Cabral, Armando Zeferino e Luís Morais)

\section{LISBOAR: O INFINITIVO DAS MINHAS LEMBRANÇAS EFÊMERAS}

Morei em Lisboa ininterruptamente de novembro de 2014 à março de 2018 para realizar o meu doutoramento em Museologia na Universidade Lusófona de Humanidades e Tecnologias (ULHT). Em 05 de março de 2018 defendi a tese intitulada "A Poética da Existêncianas Margens:Percursos de uma Museóloga-Poeta pelos Circuitos Artísticos da "Lisboa Africana"» sob a orientação do Professor Doutor Marcelo Cunha (UFBA/ULHT). Em Lisboa pude vivenciar o que é viver na casa do excolonizador. Na maior parte do tempo, não gozei da benesse de ser uma professora-doutoranda na Europa. Nem como brasileira eu era vista e sim, como africana, com todos os estereótipos, racismo, xenofobia e violência exercido sobre os corpos das africanas e dos africanos em solos europeus ditos civilizados, mas de bárbarie constante. Porém, tudo isso me possibilitou ter uma outra experiência e sem deslumbramento que muitas brancas e muitos brancos brasileiros/as têm por estarem na Europa dos "clássicos-cânones-brancos acadêmicos". Estava no "não-lugar" e na "fronteira", tendo de negociar o ser várias em uma: mulher, negra, baiana, nordestina, sulamericana, imigrante, acadêmica, arTVista, poeta. Estranhei e entranheime na cidade de Lisboa, como se ela fosse minha, e é. Conforme escreveu, Abdulai Sila: "A vida em si, já é uma viagem. Uma viagem sem local, nem data de regresso, sem direito a compensação em caso de descaminho. Por isso, todo ser humano é um nómada. Por isso, há que se sentir em casa onde quer que se esteja." (SILA, 2018, p.31). Não sinto por Lisboa um ódio extremo e nem um amor exacerbado. Construí a minha Lisboa do semba e do funaná; da moamba e da cachupa; da Linha de Sintra e da Margem Sul; dos bangladeshianos e dos nepaleses; dos Bairros da Mouraria e da Alameda; do cantor Chalo Correia e da cantora Sara Tavares; das poetas Goretti Pina e Raquel Lima; do Bar Anos60 e da Casa de Show B.leza.

Sempre falo que há três coisas que me fizeram amar Lisboa: a Luz, o Tejo e os Encontros. E o maior encontro que Lisboa me ofertou foi comigo mesma, tive de aceitar a arte que habita em mim como parte do meu ser nesta existência. E 
na fronteira entre o amor e o desamor, ganhei a prenda mais valiosa de todas: a «Poesia». Em Lisboa renasci poeta acolhida pelas águas tejianas, imersa nas águas do Paraguaçú. À poesia foi a seta indicativa dos caminhos de aconchego nas ruas frias de sol brilhante. À poesia me fez encarar de frente os meus sucessos e fracassos, as minhas alegrias e tristezas. Compreendi que é importante dizer «não sei, não quero, não gosto e não posso». À poesia me ensinou que em qualquer casa-mundo em que eu esteja, as palavras abrigam-me e acolhem-me. “[...] Procuro o meu território numa folha branca; um caderno cabe num saco de viagem. Portanto, onde quer que ponha as minhas malas, estou em casa" (DIOME, 2004, p.210). Escrever poesia na terra do excolonizador para mim foi revolucionário enquanto pessoa e pesquisadora, porque essa revolução passou pelo meu corpo, ela é minha e essa autoria ninguém arranca de mim, por isso:

Não acredito em nenhuma liberdade revolucionária que não passe pelo meu corpo de menina-mulher da pele preta; Que não venha das minhas entranhas de vida sanguínea; Que não entenda o meu mundo atlântico de ventanias intempestivas; Que não escute a minha voz de melodias cromáticas; Que não aceite as minhas ancas que rebolam num bailado de flor desabrochando na primavera de sol frio; Que não percorra as linhas retas e sinuosas da minha matéria humana de desejos ardentes... Não acredito em nenhuma liberdade revolucionária que não poetise a reinvenção fragmentada de cotidianos do meu corpo de menina-mulher da pele preta..." (GOMES, 2017, p.38).

Estudar Arte Africana Contemporânea em Lisboa, possibilitou-me perceber outras facetas do sistema de arte português. Indignava-me a perpetuação de compartimentação da África para o onanismo europeu desprazeroso. Ouvi por mais de uma vez, que, se quisesse pesquisar arte africana contemporânea dos países africanos de língua oficial não portuguesa, seria mais fácil. Se fosse de língua francesa, teria de ir para a França ou Bélgica e, se fosse de língua oficial inglesa, para a Inglaterra; e mais: sempre com a ressalva de que esses países da Europa possuíam arquivos muito bem organizados sobre as suas excolônias. Ouvia sem sorrir e indagava-me: como ainda era possível, em pleno século XXI, a Europa continuar olhando para a África e para as pessoas africanas como propriedades suas?

A falta de constrangimento alheio é algo que me constrange. Não estou dizendo que é para queimar os arquivos, porque mesmo não confiando neles, os considero importantes fontes de pesquisa. 0 meu incômodo era com a naturalidade de conceber que a arte africana contemporânea tem de ser analisada sob olhar dos países colonizadores de outrora com seus corpos investigativos brancos. Eu sei que muitas dessas mulheres e homens europeus que me deram essa "dica investigativa" não estavam estabelecendo comigo uma relação de equidade humana, pois para muitos/as deles/ as, os nossos corpos negros ainda são móveis que podem ser usados, explorados e manipulados a seu bel-prazer. 0 mais angustiante era que raramente ouvia que deveria participar da Bienal de Dakar no Senegal ou do FESPACO em Burkina Faso, mas que eu tinha de visitar o pavilhão africano da Bienal de Veneza na Itália, o que não fiz, porque não tive dinheiro para visitar nenhuma das duas bienais.

Após morar quatro anos em Portugal, constatei que tanto os/asdescendentes dos grupos colonizadores quanto os/as dos grupos colonizados saíram sequelados/as desse processo desumano. Mas as dores dos corpos negros como o meu, muitas vezes são resumidas a «mimimi», «vitimismo» ou «coitadismo», dentro e fora do espaço acadêmico. Continuamos seguindo o curso não-natural das coisas, habitando as geografias do passado e reproduzindo os desvalores coloniais no presente. Aimé Césaire, em seu texto «Discurso Sobre o Colonialismo» (1978), escreveu o seguinte:

Entre colonizador e colonizado, só há lugar para
o trabalho forçado, a intimidação, a pressão, a
polícia, o imposto, o roubo, a violação, as culturas
obrigatórias, o desprezo, a desconfiança, a
arrogância, a suficiência, a grosseria, as elites
descerebradas, as massas aviltadas. (...) Nenhum
contacto humano, mas relações de dominação e de
submissão que transformam o homem colonizador
em criado, ajudante, comitre, chicote e o homem
indígena em instrumento de produção. (...) Eu
falo de sociedades esvaziadas de si próprias, de
culturas espezinhadas, de instituições minadas,
de terras confiscadas, de religiões assassinadas,
de magnificências artísticas aniquiladas, de
extraordinárias possibilidades suprimidas. (...)
eu falo de milhares de homens sacrificados no
Congo-Oceano. Falo dos que, no momento em que
escrevo, cavam à mão o porto de Abidjan. Falo de
milhões de homens arrancados aos seus deuses, à
sua terra, aos seus hábitos, à sua vida, à vida, à
dança, à sabedoria. (CÉSAIRE, 1978, p. 25).

Penso que a arte contribue para ultrapassarmos a barreira da teoria para a prática cotidiana. Isso exige um exercício constante do repensar a 

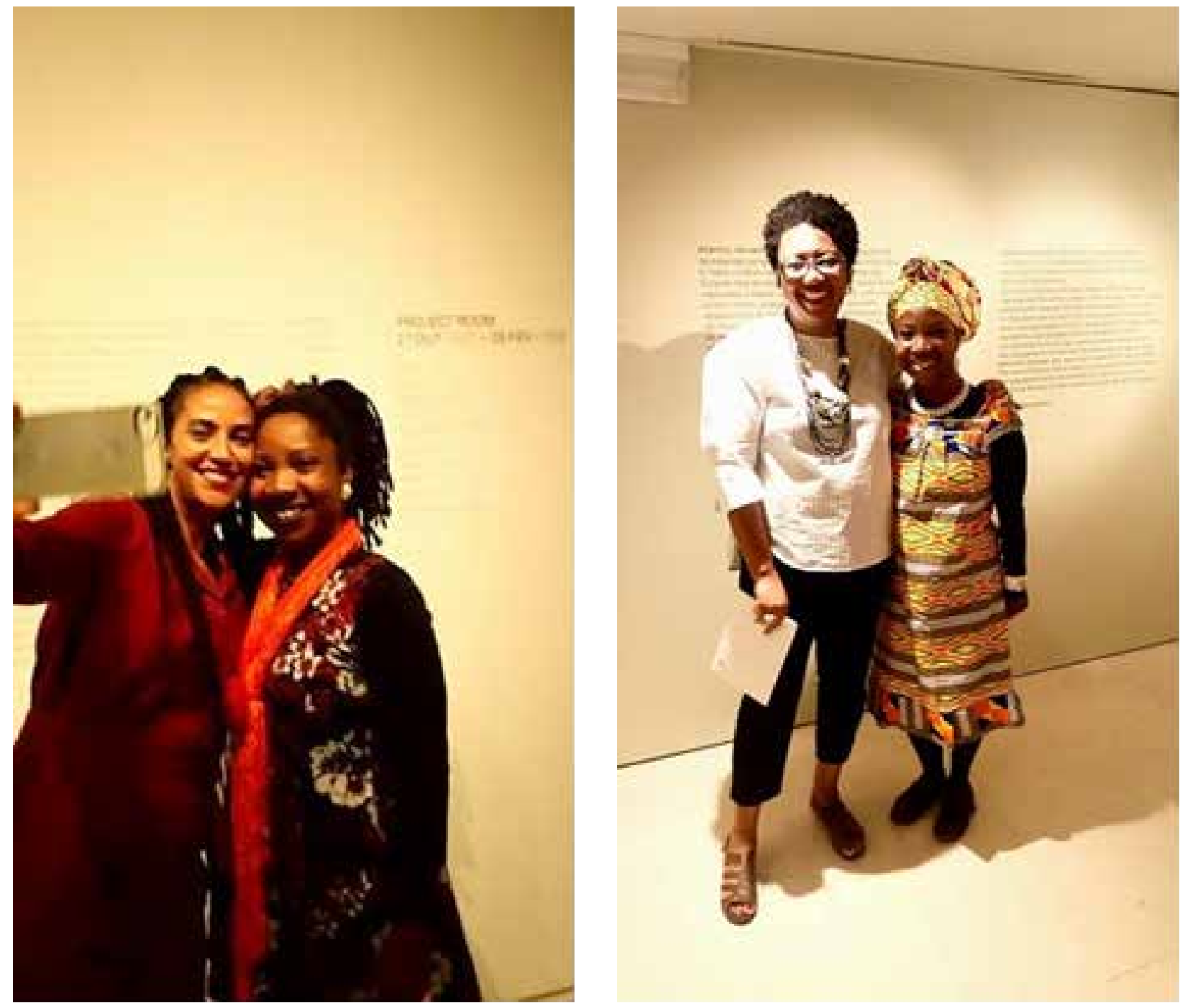

Figura 1 - Na esquerda: Eu e a artista doutora Grada Kilomba na vernissage da Exposição «Secrets to Tell» no Museu de Arte, Arquitetura e Tecnologia, 2017. Foto: Bia Leonel.

Na direita: eu e a artista doutora Rosana Paulino na abertura da Exposição «Atlântico Vermelho» no "Padrão dos Descobrimentos", 2017. Foto: Jorge Valadas.

si mesmo e a nossa relação com as pessoas ao nosso redor. Não poderia deixar de mencionar que na minha viagem inversa, encarar o desafio de fazer uma investigação em solo europeu, tendo a arte africana contemporânea como pano de fundo, foi tenso e intenso. Quase sempre ocorreu ao contrário: os europeus foram para a África ou para as Américas, a fim de investigarnos. No Brasil, lemos muitas coisas sobre nós mesmas/os escritas pelos "brasilianistas". Durante muito tempo, li muito sobre o continente africano através dos "africanistas". Estando no Velho Mundo, observei as suas chagas abertas e até agora, não canso de perguntar-me: quando os europeus e as europeias vão olhar para si mesmos/as, autoetnografar-se e desconstruir a ideia equivocada de "seres universais"?

Esta reificação colonial mistifica o europeu, tomando-o como símbolo universal do humano, e aprisiona o colonizado naqueles referenciais fetichizados que se criaram para o Negro, esperando sempre deste que seja emotivo, sensual, viril, lúdico, colorido, infantil, banal. O mais próximo possível da natureza e distante da civilização. Quando não é exótico, ou inexistente em relação àquilo que se entende por Humano, o negro é apresentado apenas como expressão de tudo o que é ruim. (FAUSTINO, 2013, p.221).

É interessante pontuar que a Europa legitimou impositivamente $\mathrm{o}$ seu conhecimento como "universal". Os brancos europeus e as brancas 
europeias quase sempre se consideram "universais", mas, na maioria das vezes, não utilizam as suas próprias teorias para pensarem a si mesmos/as e ao seu micromundo. Os seus problemas de pesquisas quase sempre, somos nós, o que eles construíram como "os outros". Paremos de ver a Europa como o modelo civilizatório, não fiquemos apenas admirando as cidades europeias como se estivéssemos num museu a ceú aberto com vitrines bem montadas, porque não é só aqui que jogamos a sujeira para debaixo do tapete. Vi muitos problemas no Velho Mundo, por lá há que se resolver a xenofobia, a islamofobia, a ciganofobia, o racismo, o machismo, a exploração da mão de obra dos/as imigrantes, a caristia da habitação, sem falar na crise do vazio das almas europeias, tão bem apresentada no livro a «A Festa da Insignificância», do Milan Kundera (2014). O bem estar social europeu, que muitas/os de nós sulamericanas/ os elogiamos, não é para todas e nem para todos. Foi irônico chegar no momento de pausa da minha tese e perceber que a minha busca diaspórica pela África perdida do meu imaginário me fez, de fato, conhecer uma parte da Europa e ter a certeza de que o cineasta Ingmar Bergman olhou a sua própria sociedade por dentro, como raros acadêmicos europeus e raras acadêmicas europeias fizeram.

\section{GRADA E ROSANA: DESCOLONIZANDO O OLHAR, O PENSAMENTO E AS IMAGENS NA CIDADE DE ÁGUAS TEJAS}

Durante a realização da minha pesquisa de doutoramento, as exposições de artistas africanos contemporâneos e de outros continentes, foram importantes lócus de reflexões para mim enquanto investigadora. Entendo que, para além de ver a exposição como uma das ações do processo comunicacional museológico, o espaço expositivo, seja no museu ou em outros locais expositivos, deve ser pensado como um lugar da multivocalidade, que exercite a convivência com diversos saberes e no qual diferentes interpretações das temáticas sejam apresentadas de forma simétrica. Não caio na armadilha perigosa de considerar que as exposições são feitas para o "público em geral", não espero que todas as exposições retratem a tudo e a todas/os e nem acredito na neutralidade curatorial e conceitual. Como museóloga sei que toda exposição trabalha com recortes. Contudo, incomoda-me quase sempre ver os mesmos recortes, nos quais muitas vezes eu, as minhas e os meus não estamos recortadas/os.
Por isso, me atento constantemente para a reflexão realizada pelo professor doutor Marcelo Cunha:

Expor é revelar/esconder, evidenciar/dissimular, incluir/excluir, iluminar/nublar elementos que seus organizadores e patrocinadores desejam tornar conhecidos ou esquecidos. Neste quadro, a exposição caracteriza-se também como espaço de luta entre poderes daí advindo exclusões, ocultamentos, seleções, promovendo silêncios e omissões. Não pode ser entendida como o fim de um processo, mas, como uma obra alimentada e realimentada permanentemente, articulada e articulando-se com outros elementos e signos do sistema de conhecimentos e de poderes instituídos [...]. (CUNHA, 2006, p.16).

As exposições das artistas Grada Kilomba e Rosana Paulino foram realizadas em 2017, no momento que estava finalizando a escrita da minha tese. Todas/ os nós que já escrevemos monografia, dissertação ou tese, sabemos que finalizar o trabalho é tão difícil e complexo quanto iniciar, especialmente, quando os pares acadêmicos não compreendem ou possuem o privilégio de não compreender o nosso trabalho. Ter visto e ouvido a Grada e a Rosana em Lisboa no processo final da tese foi de significativa relevância para compreender que a minha escrita em primeira pessoa, em «voz única de multiplicidades», é produção de conhecimento e não um devaneio egóico, nem também literatura. Ainda que eu possa ser estereotipada de agressiva, o que não sou, porque agressivo é o racismo, é o machismo, é o patriarcado, é a LGBTfobia, é a transfobia, é a xenofobia, é a arrogância acadêmica. Foi bom sentir-me à vontade e sem medo para escrever como me convém. Essas duas artistas me fortaleceram naquele momento de vulnerabilidade emocional, de profunda angústia, incertezas, mas também de uma enorme vontade de acabar aquele trabalho acadêmico para trilhar novos caminhos e alçar outros voos.

Grada Kilomba e Rosana Paulino, são duas artistas e intelectuais pelas quais tenho profunda admiração, respeito, e são referências teóricas para mim. Assumo, sou fã das duas! Permitome escrever com amor, sentimento tão caro para as pessoas negras em geral e para as mulheres negras em específico. Assim como, para mim, já não cabe mais esse "modelo clássico" da neutralidade inexistente na ciência. Ao produzir minha reflexões intelectuais na academia busco escrever com responsabilidade social, honestidade acadêmica e com atitude de afeto. Almejo a beleza da simplicidade na escrita acadêmica. Procuro a 
nobreza e a singeleza do simples que aprendi nas poesias de Adélia Prado, Manoel de Barros e Elisa Lucinda. Tento escrever textos com cheiro, com gosto, com boniteza e com afeto. Por isso, trazer as minhas lembranças expositivas para esse artigo faz parte do meu projeto de vida que é descolonizar o meu saber e a minha forma de produzir conhecimento científico. Logo, esse texto não é neutro, ele é atravessado pela minha existência vivida de mulher negra em Lisboa que teve a oportunidade de adentrar aos museus lisboetas para se ver através dos trabalhos da Grada Kilomba e da Rosana Paulino e isso não é uma consideração banal.

\section{- BIOGRAFIA DE GRADA KILOMBA}

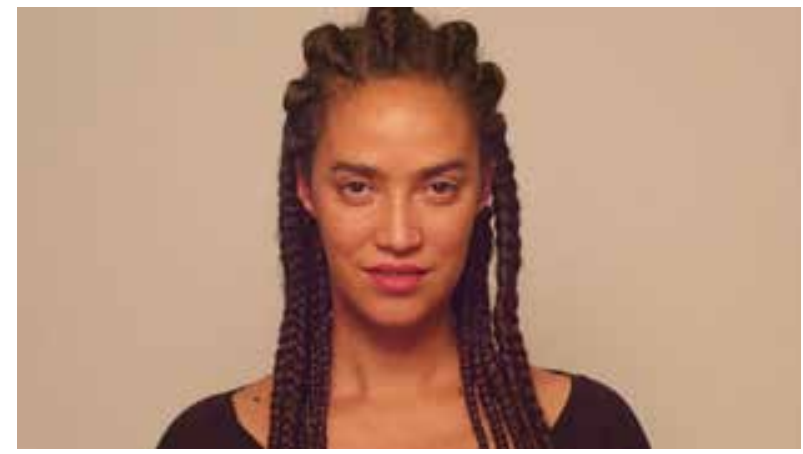

Figura 2 - Imagem retirada da página do HANGAR Centro de Investigação Artística ${ }^{3}$.

Grada Kilomba é uma artista e escritora interdisciplinar, nascida em Lisboa e residente em Berlim. Seu trabalho baseia-se em memória, trauma, raça, gênero e descolonização do conhecimento: "quem pode falar?", Sobre o que podemos falar? E "O que acontece quando falamos?" São três perguntas constantes no corpo de trabalho de Kilomba. Em seu trabalho, ela intencionalmente cria um espaço híbrido entre as linguagens acadêmicas e artísticas, e usa a narrativa como um elemento central para suas práticas decoloniais. Ela é mais conhecida por seu uso subversivo e não-convencional de práticas artísticas, nas quais ela dá corpo, voz e imagem ao seu próprio texto - o que ela descreve como Performing Knowledge - usando uma variedade de formatos como Publicação, Performance, Leitura Encenada, Instalação, Filme, Colagem de Texto, Instalação de Som e Vídeo. Ela é autora de Plantation Memories (2008) uma compilação de episódios de racismo cotidiano escritos na forma de pequenas histórias psicanalíticas; e o co-editor de Mythen, Masken und Subjekte (2005), uma antologia sobre Estudos de Whiteness Crítica. Suas obras de arte foram apresentadas internacionalmente, incluindo: 10. Berlin Biennale; Documenta 14, Kassel; 32. Bienal de São Paulo; Rauma Biennal Balticum; Art Basel; Frieze London, Cape Town Art Fair; 1-54
Feira de Arte Africana Contemporânea, Marrakech; A usina de energia, Toronto; MAAT - Museu de Arte, Arquitetura e Tecnologia, Lisboa; Galeria Avenida da Índia, Lisboa; Centro de Arte Contemporânea da WdW, Roterdão; Museu da Secessão, Viena; Museu Bozar, Bruxelas; SAVYY Contemporary, Berlim; Teatro Maxim Gorki, Berlim, entre outros. Kilomba é representada pela Goodman Gallery em Joanesburgo, África do Sul. (SITE DA GRADA KILOMBA, 2018).

\section{- biografia de rosana paUlino}

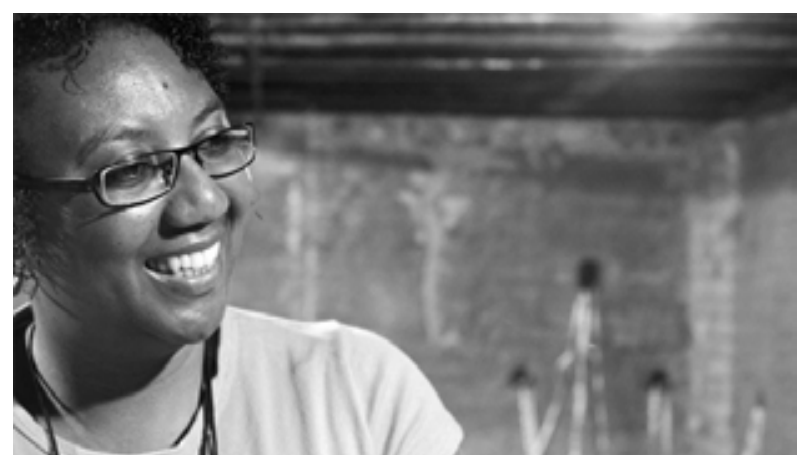

Figura 3 - Imagem retirada do site de Rosana Paulino ${ }^{4}$.

Doutora em Artes Visuais pela Escola de Comunicações e Artes da Universidade de São Paulo - ECA/USP/, é especialista em gravura pelo London Print Studio, de Londres e Bacharel em Gravura pela ECA/USP. Foi bolsista do Programa Bolsa da Fundação Ford nos anos de 2006 a 2008 e CAPES de 2008 a 2011. Em 2014 foi agraciada com a bolsa para residência no Bellagio Center, da Fundação Rockefeller, em Bellagio, Itália. Como artista vem se destacando por sua produção ligada a questões sociais, étnicas e de gênero. Seus trabalhos têm como foco principal a posição da mulher negra na sociedade brasileira e os diversos tipos de violência sofridos por esta população decorrente do racismo e das marcas deixadas pela escravidão. Possui obras em importantes museus tais como MAM - Museu de arte Moderna de São Paulo; UNM - University of New Mexico Art Museum, New Mexico, USA e Museu Afro-Brasil São Paulo. Tem participado ativamente de diversas exposições, tanto no Brasil como no Exterior, das quais se destacam as individuais na Galeria Superfície (Atlântico Vermelho, 2016); Mulheres Negras - Obscure Beuaté du Brésil. Espace Cultural Fort Grifoon à Besançon, França (2014); Assentamento. Museu de Arte Contemporânea de Americana, São Paulo, (2013); Tecido Social Galeria Virgílio, São Paulo, (2010); Rosana Paulino: Obra Gráfica. Galeria Nello Nuno, Fundação de Arte de Ouro Preto (2007) e Centro Cultural São Paulo, (2000). Destacam-se ainda as participações nas Exposições Coletivas: South-South: Let me Begin Again. Goodman Gcape Town, África do Sul (2017); La Corteza del Alma. Galeria Fernando Pradilla, Madri, Espanha (2016); Territórios: Artistas 
Afrodescendentes no Acervo da Pinacoteca. Pinacoteca do Estado, São Paulo, SP (2015); Incorporations. Europália 2011. La Centrale Eletrique, Bruxelas, Bélgica; roots and more: the journey of the spirits. Afrika Museum, berg en dau, Holanda (2009); Áfricas-américas: Encuentros convergentes: ancestralidad y contemporaneidad. Bienal de Valencia, Valencia, Espanha. In someone else's skin - bard college - Nova York, USA (2007). Mulheres artistas / olhares contemporâneos MAC/US/. São Paulo, SP, (2007); Trienal poli/ gráfica de san juan: América Latina y el Caribe San Juan, Porto Rico; IVBienal do Mercosul - Cais do Porto - Rio Grande do Sul, RS, Brasil; Côte à côte - art contemporain du Brasil - capcmusée d'art contemporain - Bordeaux - França; século XX- Arte do Brasil - Fundação Calouste Gulbenkian - Lisboa - Portugal e Bienal Brasil + 500 - Arte Afro-Brasileira - Fundação Bienal de São PauloSP - Brasil. (SITE DA ROSANA PAULINO, 2018).

Os trabalhos da Rosana Paulino, já conhecia desde a graduação em Museologia na Universidade Federal da Bahia (UFBA), mas evidentemente que não me foram apresentados pelas professoras e professores que tive na Escola de Belas Artes (EBA/UFBA) e sim, por um ex-educador do Museu Afro Brasil de São Paulo - SP, que sabia do meu interesse pelas produções artísticas de artistas negras e negros, e me falou da obra «Bastidores» da referida artista. Desde então, passei a acompanhar o trabalho da Rosana, não com o objetivo de investigá-lo academicamente, mas sim, pela força transformadora da sua produção visual, que é tão significativa para mim e não está traduzível em palavras.

Tive contato com os trabalhos da Grada Kilomba, no período da $32^{\mathrm{a}}$ Bienal de São Paulo - SP, em 2016, da qual ela participou. Apesar de estar em Lisboa, acompanhava as notícias da Bienal pela internet e comecei a ver amigas e amigos postando reportagens sobre a artista e falando da Residência Artística que ela estava fazendo no Instituto Goethe de Salvador-BA. Lembro-me que numa tarde fria de outono parei de escrever a tese e fui ler e ouvir a Grada. Fiquei fascinada pelo seu trabalho e pela sua voz, me questionei como até aquele momento não a conhecia. Senti a frustração do desconhecimento que não é aleatório e nem voluntário. E mais, fiquei com o gosto ocre na boca da minha imaginação porque os trabalhos dela estavam sendo expostos no Brasil e eu estava em Portugal. Para mim, nada supera a experiência dos meus sentidos com as obras de arte ao vivo e nem sempre à cores. As plataformas online não me satisfazem, não saciam

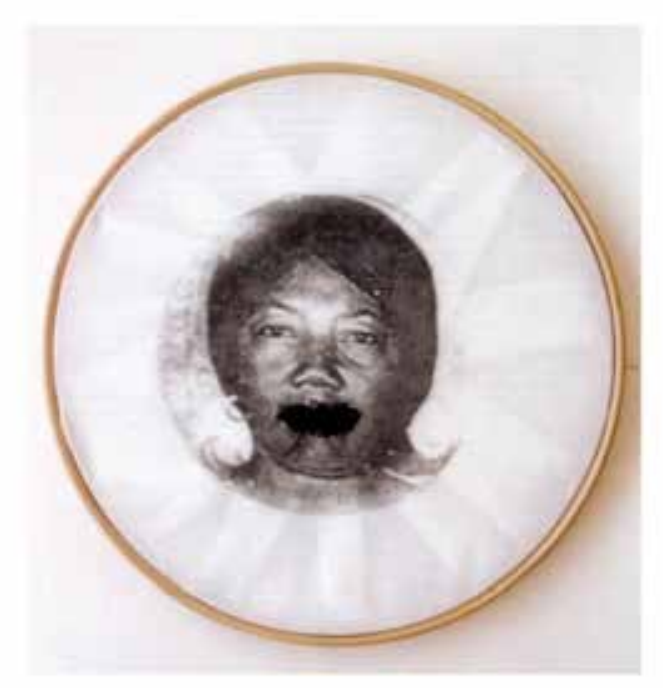

Figura 4 - Imagem transferida sobre tecido, bastidor e linha de costura. 30,0 cm diâmetro - $1997^{5}$.

a minha gana de fruição. Porém, sigo acreditando nos presentes da vida e antes de encerrar o meu ciclo de estadia em Lisboa, eu e a cidade de águas tejas fomos presenteadas com duas exposições da artista e mais duas palestras as quais assisti. Uma no Teatro Maria Matos, com a mediação da jornalista mestra Carla Fernandes e a outra no Hangar - Centro de Investigação Artística, mediada pela professora doutora Manuela Ribeiro Sanches.

\section{- EXPOSIÇÕES À BEIRA DO TEJO}

As exposições «Atlântico Vermelho» da Rosana Paulino inaugurada no dia 14 de outubro de 2017 no "Padrão das Invasões", oficialmente denominado de "Padrão dos Descobrimentos", no âmbito das comemorações de "Lisboa - Capital Ibero-Americana de Cultura (2017) e as da Grada Kilomba «The Most Beautiful Language»" na Casa

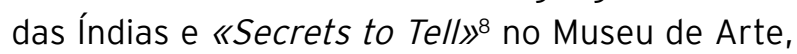
Arquitetura e Tecnologia (MAAT), ambas abertas paralelamente no dia 26 de outubro de 2017, coincidentemente ou não, estavam abrigadas em espaços localizados na margem do Tejo, rio este, que deságua no Atlântico e como nos diz a professora, intelectual e feminista negra Carla Akotirene, é preciso:

[...] adotar o Atlântico como locus de opressões cruzadas, pois acredito que esse território de águas traduz, fundamentalmente, a história e a migração forçada de africanas e africanos. As águas, além disto, cicatrizam feridas coloniais causadas pela Europa manifestas nas etnias traficadas como mercadorias, nas culturas afogadas, nos 


\section{So, why do I write?}

Figura 5 - Grada Kilomba, The Desire Project, 2015-2016, instalação de vídeo em três canais, HD, som, 2'46", em loop, duas impressões impressas e uma instalação de altar (miçangas, velas, tigela com café, cachimbo, vidro de água, flor, fezes de madeira).

Créditos: Música de Moses Leo. Encomendado pela $32^{a}$. Bienal de São Paulo ${ }^{6}$.

binarismos identitários, contrapostos humanos e não humanos. No mar Atlântico temos o saber duma memória salgada de escravismo, energias ancestrais protestam lágrimas sob o oceano. (AKOTIRENE, 2018, p. 15).

As exposições estavam em espaços museológicos e galeristico no bairro de Belém, local incomodativo para mim, não pelo grande fluxo de turistas e nem pela interminável fila na Confeitaria do Pastel de Belém, mas sim pelo indigesto "Padrão dos Descobrimentos". Todas às vezes, que passava naquele bairro, sentia-me violentada, com aquele patrimônio que não me representa, o considero desrespeitoso com as memórias dos meus ancestrais africanos e indígenas. Como investigadora sei que os lugares podem ser ressignificados por diferentes sujeitas e sujeitos, no entanto, marcos como o "Padrão", símbolo materializado de violências e desumanização não precisam ser reificados e, evidentemente, que por mim, não será. Mas por conta dos acasos da vida, após três anos em Lisboa, pela primeira vez adentrei aquele lugar no dia 02 de Julho de 2017, data na qual nós baianas e baianos comemoramos o dia «Independência da Bahia»», para realizar uma visita mediada à convite do Professor Doutor Pedro Schacht da Universidade de Ohio, Estados Unidos. Mediamos em parceria uma visitação na mostra «Racismo e Cidadania $»^{10}$. Regressei a este local por conta da exposição «Atlântico Vermelho» e dei-me conta que as águas com a sua imensa generosidade estava nos ofertando outras narrativas sobre nós mesmas/os a partir de duas pérolas negras atlânticas.

Considero que as exposições «At/ântico Vermelho», "The Most Beautiful Language» e

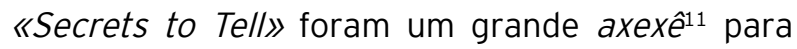
despachar as memórias traumáticas e violentas do colonialismo português. Os nossos ancestrais africanos que foram escravizados aguardavam por essa cerimônia imagética. Acredito que houve festa no Orum $^{12}$. Não foi uma simples coincidência três exposições num bairro tão evocativo das memórias colonialistas portuguesa, tendo as águas como condutora dos caminhos a seguir. Os corpos negros como o meu que adentraram aquelas salas expositivas, sabiam que não se tratava apenas de exposições no sentido racionalista euro-ocidental, 

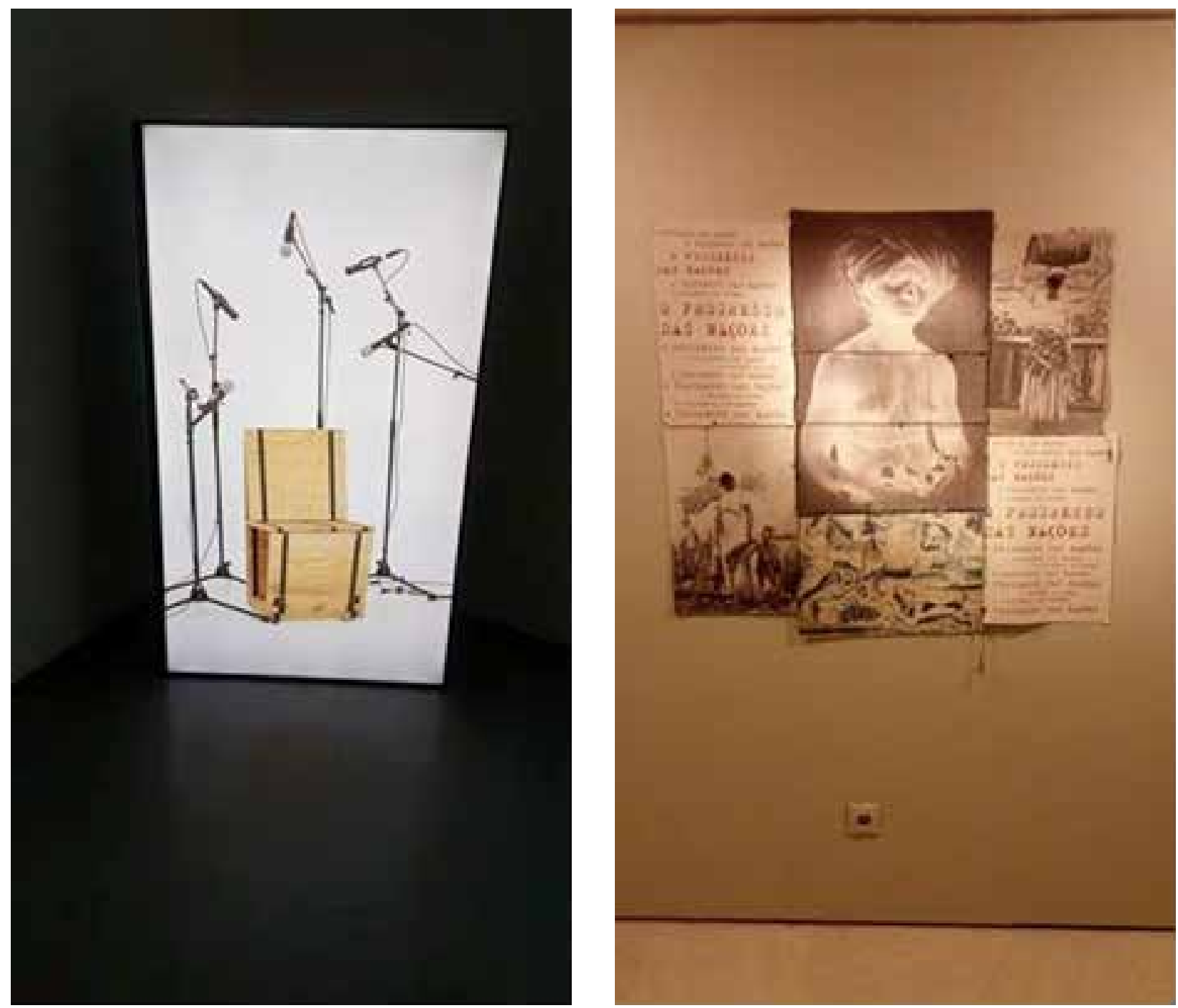

Figura 6 - Na esquerda: Obra da artista doutora Grada Kilomba na Exposição «The Most Beautiful Language», na Galeria das Índias, 2017.

Na direita: Obra da artista doutora Rosana Paulino na Exposição «Atlântico Vermelho», no "Padrão dos Descobrimentos", 2017. Fotos: Luzia Gomes Ferreira.

mas havia ali toda a simbologia das nossas histórias silenciadas, das nossas memórias fraturadas, das nossas emoções sufocadas, das nossas existências sequestradas. Os trabalhos artísticos apresentados por Grada Kilomba e Rosana Paulino, ecoaram para além das paredes de pedra e cal, foram oferendas ofertadas ao terreiro-mundo para que nós seres animados pelo sopro da vida nesse território ocidental dito civilizado, compreendamos que a escravização das pessoas africanas foi um crime contra a humanidade. E a humanidade não é uma "característica inerente" aos corpos brancos.

Participei das vernissages das três exposições e voltei mais duas vezes em ambas. A cada visita percebia um detalhe que não tinha percebido na visita anterior. Constatei que Grada Kilomba e Rosana Paulino no meu olhar de visitante, trouxeram reflexões semelhantes com visualidades totalmente distintas. Ambas, nos colocaram de frente com os traumas coloniais, nos apresentaram a não neutralidade da ciência e nos mostraram como a escravidão transformou pessoas em coisas e isso reverbera até hoje em nossas sociedades, tendo o racismo como a materialização eficaz desse projeto desumanizador. Para mim, as três exposições foram o que coloquialmente posso chamar de "soco no estômago"da sociedade portuguesa. Uma sociedade que se forja no falacioso discurso da "multiculturalidade", mas é profundamente racista tanto quanto a brasileira. E não há racismo "melhor" ou "pior", não se mede 


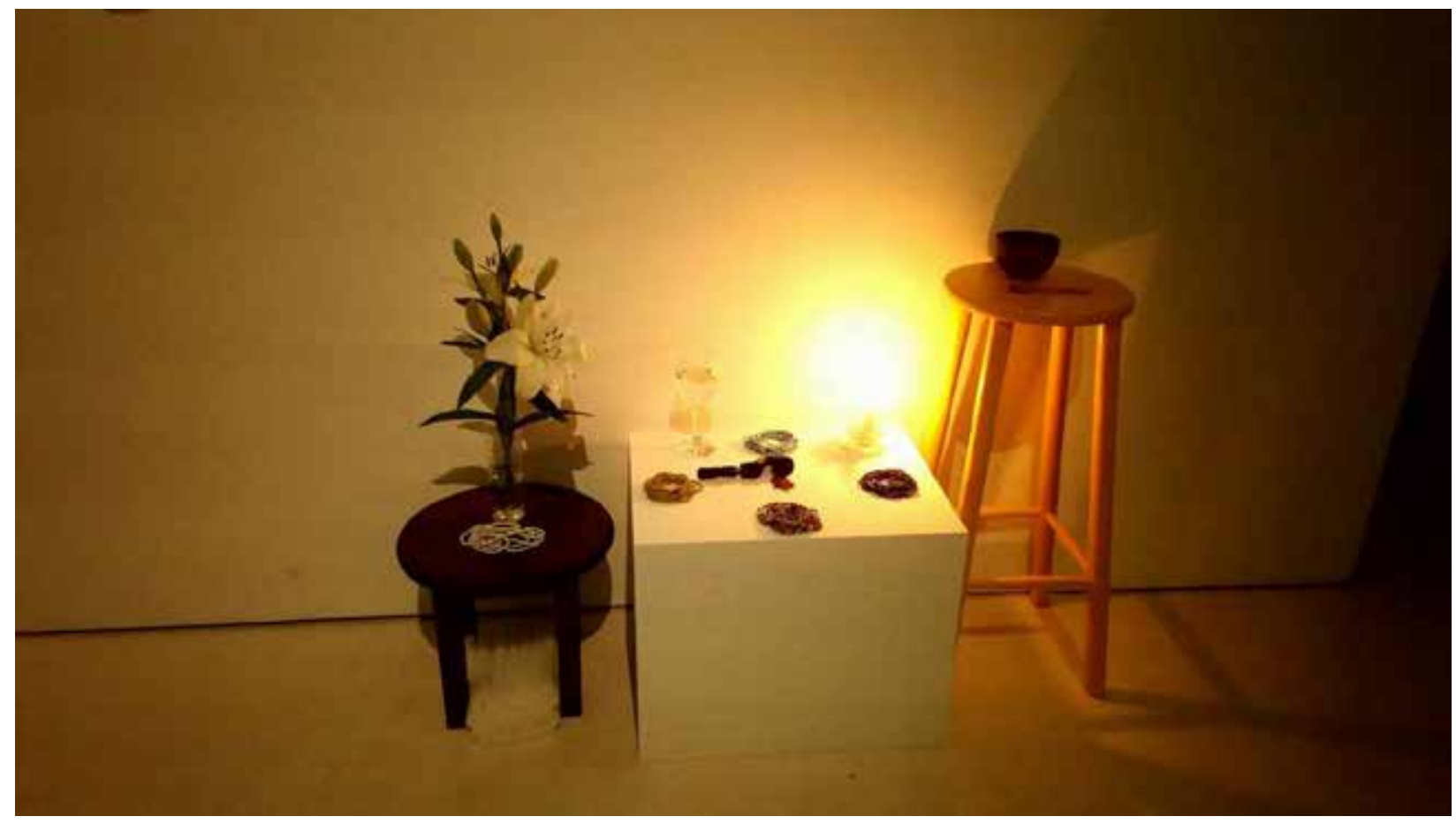

violências na escala do "ruim" ou "menos ruim", toda e qualquer forma de discriminação é violenta e desumanizadora.

Se a Rosana Paulino nos apresentou o Atlântico como o "[...] mar que foi tingido de sangue pelo tráfico escravista e que liga Brasil em uma duas suas pontas e África na outra ponta." (PAULINO, 2017) ${ }^{13}$. Ou seja, o Atlântico não foi o lugar do encontro harmonioso entre portugueses, africanos e as sociedades indígenas das Américas inventadas, mas sim o local da dor, da opressão, da humilhação e da supremacia branca. Por outro lado, a Grada Kilomba (2018) nos trouxe a música "[...] como narração, como voz, porque a música tem tido este papel político de resistência na diáspora africana que é muito importante, que tem ocupado muitos espaços através da música, do som[...]." (KILOMBA, 2017 $)^{14}$. A música foi e contínua sendo um espaço de reivindicação e de existência das pessoas negras, seja no Brasil, seja em Portugal, como observei. Água e Som elementos construtores de memórias negras nas duas margens atlânticas e também de outros oceanos.

Inspirada no nome do livro do sociólogo Paul Gilroy, Atlântico Negro, penso neste mar que liga dois pontos, África e Brasil, e que sofreram processos de aniquilamento e subjugação de suas populações, tendo as ideias de ciência, religião e de progresso sido usadas para justificar os mais aterrorizadores abusos. Para realizar os trabalhos desta expoosição me debrucei, com um misto de admiração, curiosidade e, muitas vezes, revolta sobre imagens produzidas no Brasil e que retratavam a flora, a fauna e principalmente as gentes num mesmo plano, como objetos a serem explorados, elementos pitorescos em uma paisagem exótica, ao invés de seres dotados de humanidade. Esta postura reforçou a ideia de um direito natural sobre outras terras e povos justificando o colonialismo, não só exercido nas Américas mas, posteriormente, na exposição européia em África. (PAULINO, 2017, p.08-09). 


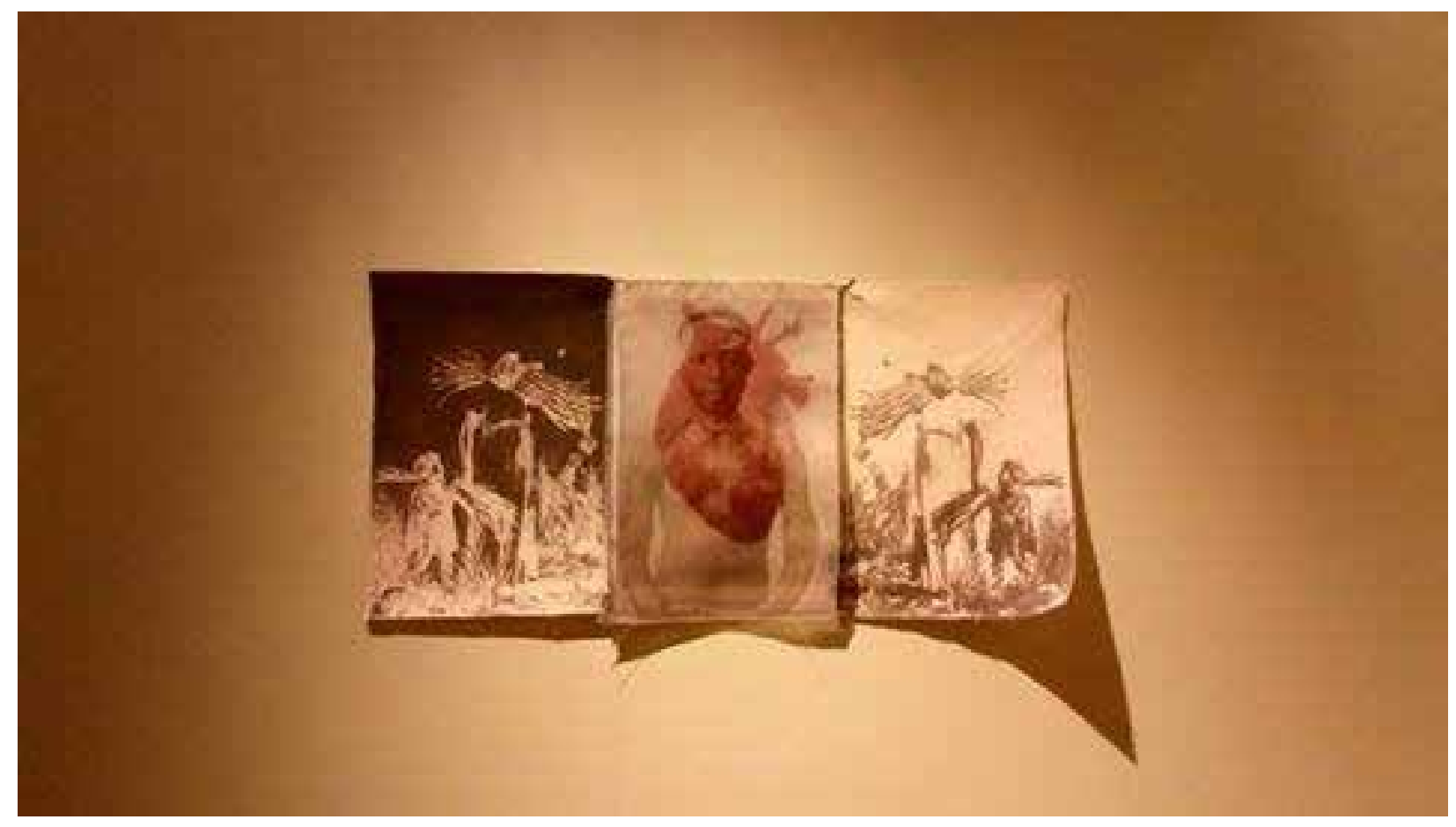

Figura 7 - Na esquerda: Obra da artista doutora Grada Kilomba na Exposição «Secrets to Tell» no Museu de Arte, Arquitetura e Tecnologia (MAAT), 2017.

Foto: Luzia Gomes Ferreira

Na direita: Obra da artista doutora Rosana Paulino na Exposição «Atlântico Vermelho», no "Padrão dos Descobrimentos", 2017.

Foto: Luzia Gomes Ferreira

Detesto quando tocam no meu cabelo.

Me perguntam de onde sou.

Eu nunca senti isso antes no meu corpo.

Nos meus dedos.

Eu expliquei para ela que não gosto disso.

Ela disse-me que o amigo dela Cubano gosta.

Eu cresci a ouvir esta palavra.

Tem que ser algo mau.

Ele desculpou-se imediatamente.

Como é que eu lavo o meu cabelo.

Com água e champô!

Ela suicidou-se.

Eu acho que ela estava muito sozinha.

Nem pude acreditar.

Ele cheirou o meu cabelo e cantou aquela canção.

Sobre macacos.

Eu tive que ser melhor que todos os outros.

Três vezes.

Quatro.

Negra e esperta.

Zangada.

Eu não sou agressiva.

Zangada, porque isso é agressivo.

Sim, eu penteio-me.

Eu não quero ser melhor.
Imagina, ser a única pessoa negra na família.

Eu não quero ser pior.

Tive que me aperceber do perigo que corria.

Eu tive que ler muito.

Aprender.

Estudar.

Eu li muitos livros."

(KILOMBA, 2017, Exposição «The Most Beautiful Language»).

No primeiro dia que revisitei as exposições da Grada Kilomba, a re-encontrei visitando a sua própria exposição «Secrets to Tell» no MAAT, na companhia da sua família. Ela me cumprimentou com o seu sorriso afetuoso, nos falamos e eu the disse que ela era para mimuma referência teórica, a qual não me decepcionei em conhecer pessoalmente. Fiquei percorrendo as salas expositivas e como sempre faço, há momentos que paro e observo as outras e os outros visitantes. Vi tantas pessoas brancas naquelas salas com muita desenvoltura no auge das suas sapiências artísticas, e fiquei perguntando-me: 


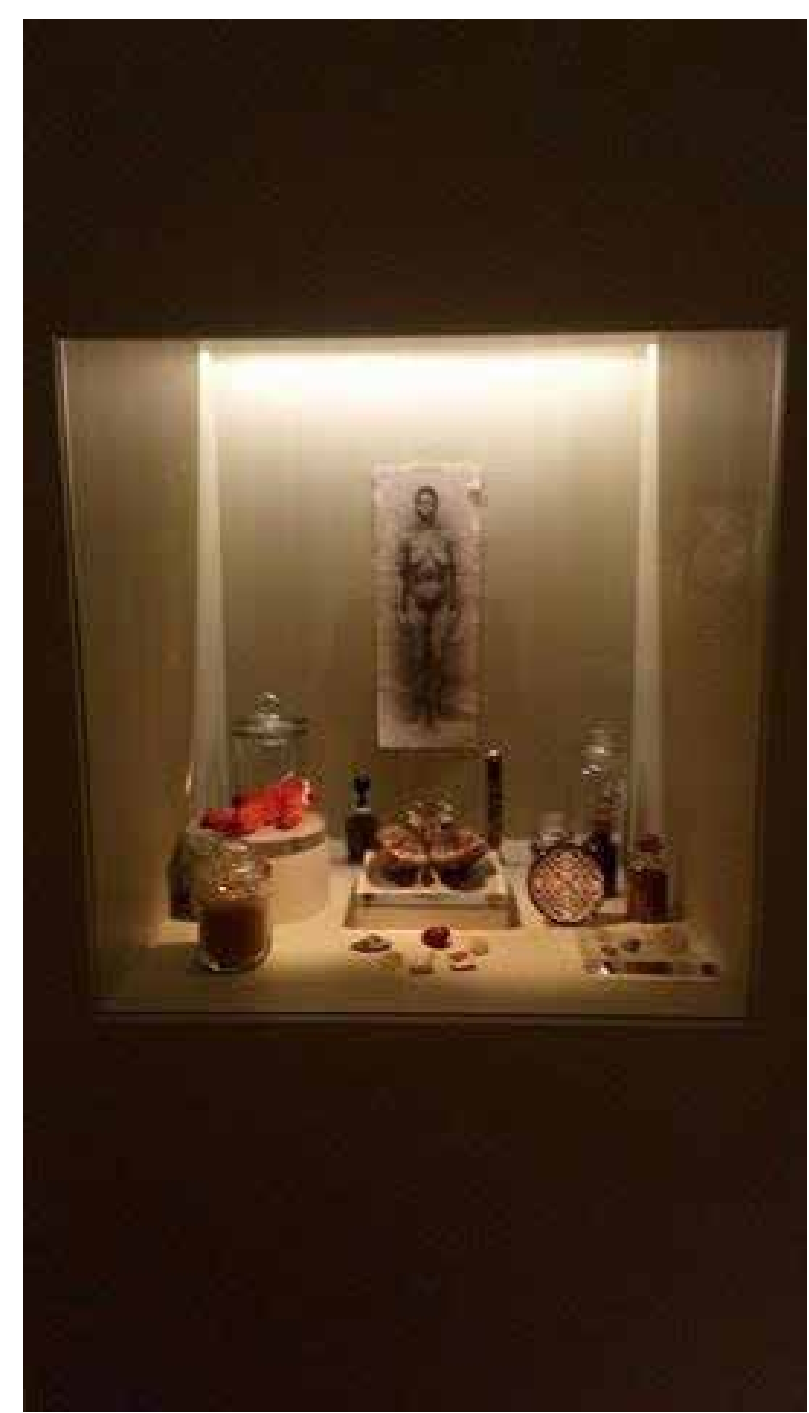

Figura 8 - Obra da artista doutora Rosana Paulino - Gabinete de Curiosidades, Exposição «Atlântico Vermelho», no "Padrão dos Descobrimentos", 2017. Foto: Luzia Gomes Ferreira

- será que essas pessoas refletem criticamente sobre o que estão vendo e ouvindo? Óbvio que não tenho resposta para a minha pergunta, porém, com a mais profunda sinceridade do meu âmago, realmente espero que aquelas pessoas tenham refletido sobre o que viram e ouviram naquela exposição.

Na vernissage da Exposição «Atlântico Vermelho» da Rosana Paulino, após percorrer as salas expositivas fui para o mirante do "Padrão dos Descobrimentos" e fiquei contemplando o Rio Tejo. Era um fim de tarde bucólico e eu fiquei ali inebriada com o céu alternando de cores e com reflexo na água. Enquanto contemplava esse espetáculo natural a olho nu, absorvia a exposição. Por mais que já conhecesse o trabalho da Rosana, foi muito impactante ver aquela exposição naquele lugar e na cidade de Lisboa. Fiquei mexida, pensando o que era o meu país (Brasil) e o que vivia em Portugal, habitando a minha pele preta de imigrante. As palavras davam voltas na minha cabeça e acabei escrevendo o poema que segue abaixo. Naquele momento só conseguia traduzir o significado daquela mostra em estado de poesia.

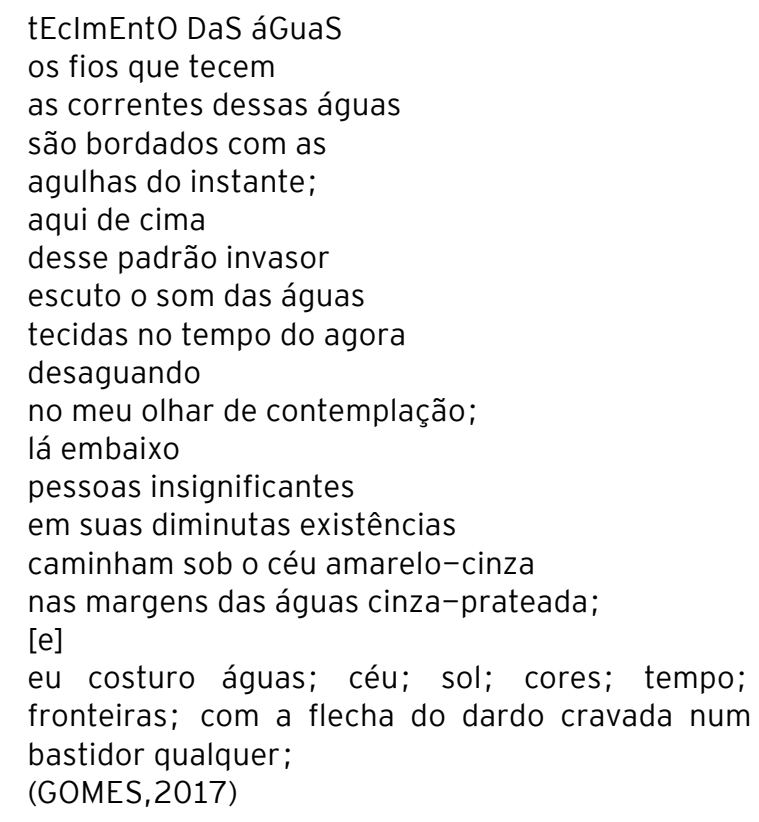

Como qualquer pessoa, queremos estar à vontade onde os nossos corpos negros circulem e, necessariamente, não é o que ocorre nos eventos e espaços artísticos. Porém, ao visitar as exposições da Grada Kilomba e da Rosana Paulino, foi primordial para mais uma vez confirmar que apesar das instituições, - os museus, as galerias e as academias -, muitas vezes serem inóspitas e inacessíveis para muitas/os de nós, precisamos estar nesses espaços, questionando-os e propondo outras narrativas, para que, de fato, possamos caminhar conjuntamente rumo a um processo de descolonização dos conhecimentos científicos e artísticos para, assim, termos direito às nossas próprias memórias num fluxo fluido do "eu" para o "nós".

\section{AGRADECIMENTOS FINAIS}

Finalizo esse texto agradecendo a Grada Kilomba e a Rosana Paulino, conforme fiz nos agradecimentos na minha tese, porque acredito que é preciso agradecer em vida. Foi reconfortante e acolhedor ouvi-las falar com toda profundidade, brandura, firmeza e conhecimento artístico-acadêmico, naquele momento de incertezas e inseguranças que a finalização da 


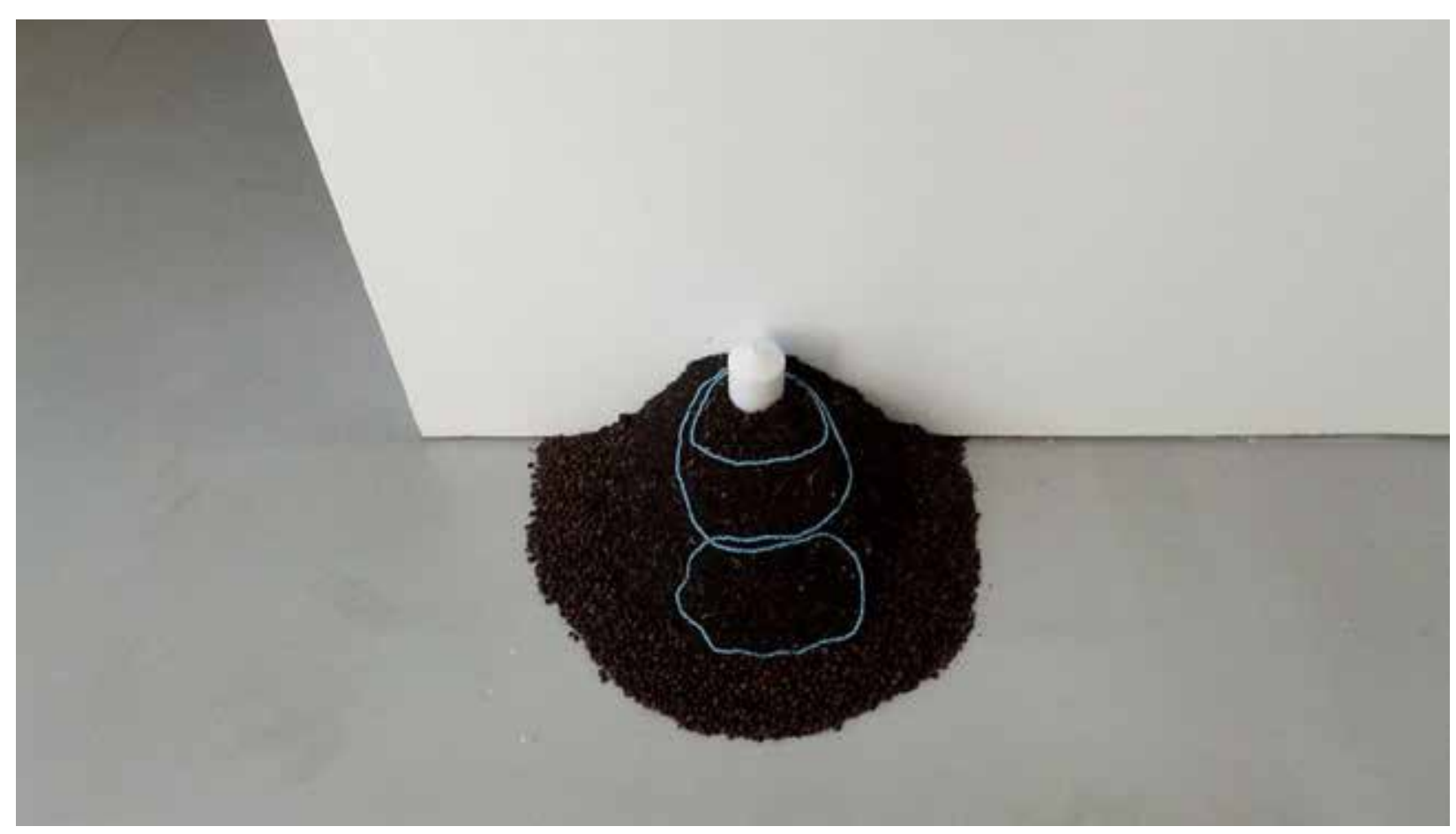

Figura 9- Obra da artista doutora Grada Kilomba na Exposição «Secrets to Tell» no Museu de Arte, Arquitetura e Tecnologia (MAAT), 2017. Foto: Luzia Gomes Ferreira.

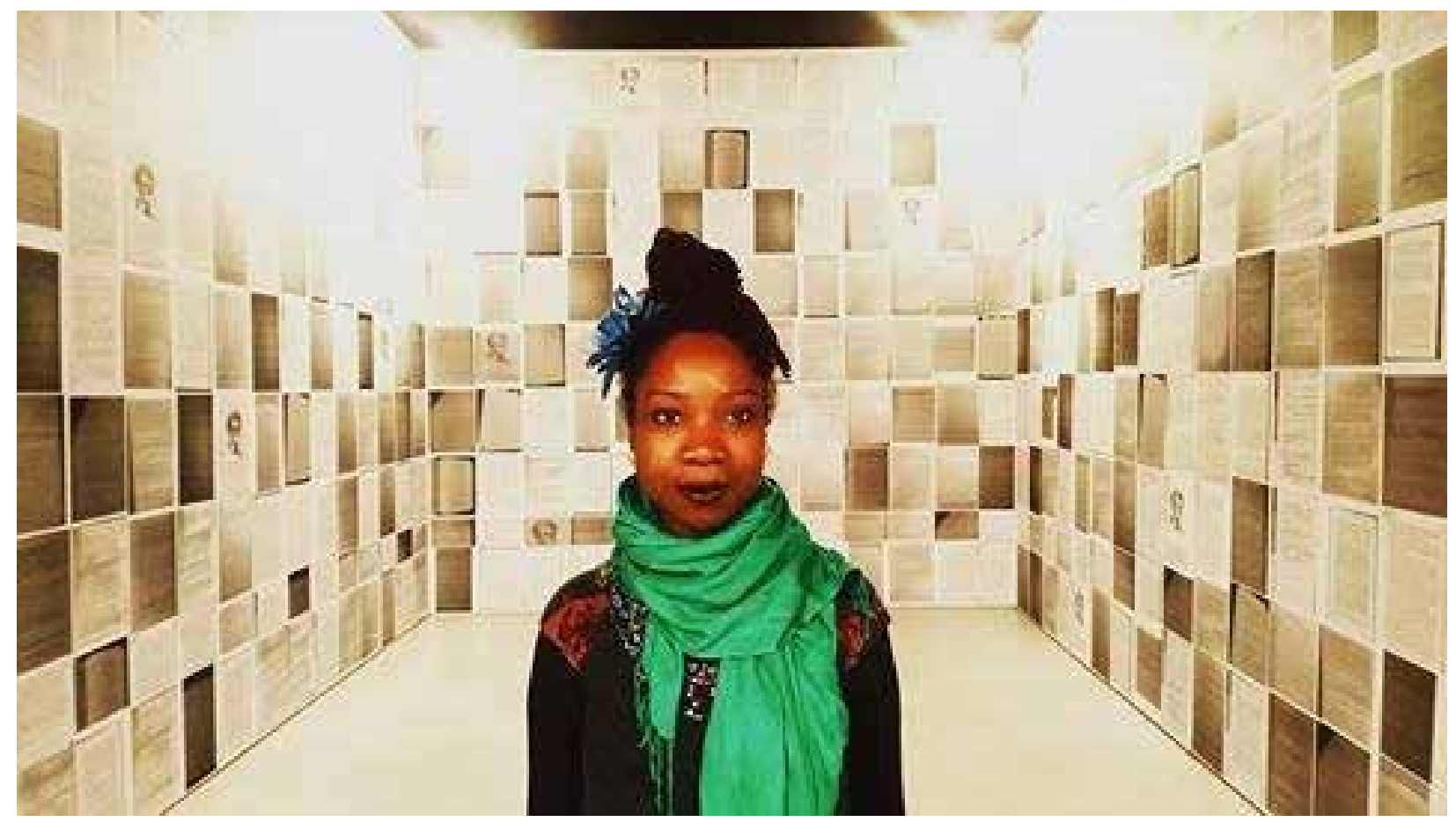

Figura 10 - Eu (Luzia Gomes Ferreira) revisitando a exposição «The Most Beautiful Lanquage», da Grada Kilomba na Galeria das Índias, 2017 Foto: visitante anônima da exposição. 
tese disparou em mim. Talvez, elas nunca leiam esse artigo ou muito menos a minha tese, mas o fato delas terem me levado a escrever esse texto já é motivo o suficiente para agradecê-las, para que compreendamos que representatividade negra importa e que as mulheres negras estão em cena produzindo arte, subvertendo a ordem do patriarcado, o qual exercita cotidianamente o descrédito às nossas existências.

Agradeço a oportunidade de escrever esse artigo desenquadrado, mas com profunda seriedade ao meu trabalho de pesquisadora, professora, arTVista e poeta. Aprendi que ser professora numa universidade pública é construir teorias inclusivas, nas quais nos vejamos, porque nossos ancestrais africanos e indígenas nos legaram essa herança, somos a materialização dos seus sonhos e lutas por liberdade. A teoria em qualquer área do conhecimento é para libertar e não para aprisionar, achincalhar e muito menos deslegitimar. "[;] a diáspora negra deve buscar caminhos discursivos em atenção aos acordos estabelecidos com antepassados . (;) a língua escravizada esteve amordaçada politicamente, impedida de tocar seu idioma, beber da própria fonte epistêmica cruzada de mente-espírito." (AKOTIRENE, 2018, p. 15).

Por fim, esse artigo foi o meu exercício inalcançável de sair da minha caixinha de museóloga-antropóloga e me colocar enquanto visitante-poeta, que olha o mundo em estado de poesia. Foi a busca de refletir sobre a importância das artes em nossas vidas vividas. Foi a tentativa de costurar água e som com fios de equidade e bordar no bastidor da simetria, percursos de encontros imagéticos no interior do cubo arcoíris. Almejo que no Brasil e em Portugal num futuro bem próximo, exposições como a da Grada Kilomba e da Rosana Paulino, sejam constantes e não raras pérolas negras. aXé!

\section{NOTAS}

01. Excerto da Música «Pérola Negra» do cantor e compositor Luiz Melodia, falecido em 04 de agosto de 2017.

02. Banda turca composta pela vocalista Michal Elia Kamal, - israelense de origem iraniana, que canta em turco e em hebraico -, pelo músico turco Metehan Çifçi e pelo músico francês Julien Demarque.

03. Imagem disponível em: <https://hangar.com. pt/grada-kilomba-conversa-artista/>. Acedida em 11 de novembro de 2018, às 13h10min.

04. Imagem disponível em: <http://www. rosanapaulino.com.br/>. Acedida em 11 de novembro de 2018, às $13 \mathrm{~h} 15 \mathrm{~min}$.

05. Imagem disponível em:<http://www. rosanapaulino.com.br/>. Acedida em 11 de novembro de 2018, às $13 \mathrm{~h} 46 \mathrm{~min}$.

06. Imagem disponível em:<http://gradakilomba. com/works-2/>. Acedida em 11 de novembro de 2018, às $14 \mathrm{~h} 22 \mathrm{~min}$.

07. A exposição «The Most Beautiful Language», na Galeria das Índias, teve curadoria de Gabi Ncobo.

08. A exposição «Secrets to Tell» no MAAT, teve curadoria de Inês Grosso.

09. "Um dos fatos relegados ao esquecimento pela história oficial refere-se às guerras ocorridas durante o processo de independência do Brasil. Nesse sentido, é preciso dar o devido valor à participação da Bahia na luta pela emancipação política do País, cujo ápice se deu com a expulsão definitiva das tropas portuguesas, no dia 2 de julho de1823. Trata-se de uma das páginas mais marcantes do nosso passado! A Bahia foi o principal palco das guerras da independência, tendo sido o local onde o conflito durou mais tempo (cerca de um ano e cinco meses) e que mobilizou o maior contingente de pessoas, contando, inclusive, com a participação de segmentos populares. Foi na província baiana que o território brasileiro correu sério risco de fragmentar-se." (SÉRIE HISTÓRIAS NÃO CONTADAS, 2015). Disponível em: <http:// www2.camara.leg.br/a-camara/visiteacamara/ cultura-na-camara/arquivos/dois-de-julho2014-a-independencia-do-brasil-na-bahia>. 
Acedido em 12 de novembro de 2018, às 10h00min.

10. Esta exposição também ocorreu no âmbito das comemorações de Lisboa - Capital IberoAmericana de Cultura. E teve a curadoria científica e investigação de Francisco Bethencourt (Portugal).

11. Ritual fúnebre do Candomblé, no qual a cor do luto é o branco.

12. Palavra de origem Yorubá, usada nos terreiros de Candomblé para se referir ao céu, ao mundo não terreno.

13. Esta fala está no vídeo «Atlântico Vermelho», no qual a artista apresentada detalhadamente a concepção conceitual da exposição. Disponivel em: <https://vimeo.com/252096733>. Acedido em 11 de novembro de 2018, às $17 \mathrm{~h} 40 \mathrm{~min}$.

14. Esta fala está no vídeo «Grada Kilomba em antevisão às exposições e conversas em Lisboa», no qual a artista apresenta detalhadamente a concepção conceitual da exposição. Disponível em: $\quad<$ https://www.youtube.com/watch?v=9xhyouAirA\&t=281s $>$. Acedido em 11 de novembro de 2018 , às $17 \mathrm{~h} 42 \mathrm{~min}$.

\section{REFERÊNCIAS}

AKOTIRENE, Carla. O Que É Interseccionalidade? Coordenação Djamila Ribeiro. Belo Horizonte (MG): Letramento: Justificando, 2018. (Feminismos Plurais).

CÉSAIRE, Aimé. Discurso sobre o Colonialismo. $\left(1^{\mathrm{a}}\right.$ ed.). Tradução de Noémia de Sousa. Lisboa: Livraria Sá da Costa Editora. 1978.

CUNHA, Marcelo N. Bernardo. da. Teatro de Memórias, Palco de Esquecimentos: Culturas Africanas e das diásporas negras em exposições. Tese apresentada ao Programa de Estudos Pós-Graduados em História da Pontifícia Universidade Católica de São Paulo (PUC). 2006.

DIOME, Fatou. Kétala. Tradução: Rita Bueno Maia.

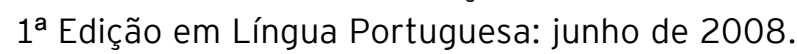
Coleção Raízes. Lisboa, Portugal.

FANON, Franzt. Racismo e Cultura. Intervenção de Frantz Fanon no $1^{\circ}$ Congresso de Escritores e
Artistas Negros em Paris, em setembro de 1956. In: Manuela Ribeiro Sanches (org.) (2012). Malhas que os impérios tecem: textos anticoloniais, contextos pós-coloniais. Lisboa: Edições 70. (1956/2012).

FAUSTINO, Deivison Mendes. Colonialismo, racismo e luta de classes: a atualidade de Frantz Fanon. In: Anais do V Simpósio Internacional Lutas Sociais na América Latina "Revoluções nas Américas: passado, presente e futuro" (pp.216-232). 2013. Disponível em: <http:// www.uel.br/grupo-pesquisa/gepal/v16_ deivison_GI.pdf.> Acedido em 11 de novembro de 2018, às 22h11min.

GOMES, Luz. IIbErdAdE RevOIUcIOnÁrIA dO CoRPo. In: Carvalho, A., et al. Coletânea Djidiu -

A Herança do Ouvido: Doze formas mais uma de se falar da experiência negra em Portugal. Lisboa: Edição VADA|ESCREVI. 2017.

GOMES, Luz. tEcImEntO DaS áGuaS. In: Memórias da Saudade. 2018, no Prelo.

KILOMBA, Grada. Texto-Obra na Exposição «The Most Beautiful Languagen, na Casa das Índias, Lisboa - PT, 2017.

KILOMBA, Grada. "Grada Kilomba em antevisão às exposições e conversas em Lisboa". In: Vídeo. Imagem e edição: Pedro Gancho; Som: Sara Morais; Entrevista: Rita Tomás; Produção: Maria Matos Teatro Municipal. Agradecimentos: Galerias Municipais de Lisboa e MAAT. Disponível em: $\quad<$ https://www.youtube.com/watch?v=9xhyouAirA\&t=281s $>$. Acedido em 11 de novembro de 2018, às $17 \mathrm{~h} 42 \mathrm{~min}$.

KILOMBA, Grada apud RIBEIRO, Djamila. "O Racismo é uma Problemática Branca", diz Grada Kilomba. In: Quem Tem Medo do Feminismo Negro? Djamila Ribeiro - $1^{a}$ ed. São Paulo: Companhia da Letras, 2018. pp. 108-112.

LABRA, Daniela. Sem Paternalismo Nem Vitimização. In: Revista Select: Arte e Cutlura Contemporânea. Edição de Aniversário 7 anos. Set/Out/Nov/2018. pp. 103-104.

LIMA, Daniel. Perspetivas de mundo, conversa com Daniel Lima, curador de AGORA SOMOS TODXS NEGRXS. In: BUALA. 13 de novembro de 2017. Disponível em: <http://www.buala.org/pt/ 
cara-a-cara/perspetivas-de-mundo-conversacom-daniel-lima-curador-de-agora-somostodxs-negrxs> Acedido em 11 de novembro de 2018, às 22h03min.

MIRZOEFF, Nicholas. "A 'teoria' não são só palavras numa página, mas também coisas que se fazem", entrevista com Nick Mirzoeff. In: BUALA. 11 Junho 2018. Disponível em: <http://www.buala. org/pt/cara-a-cara/a-teoria-nao-sao-sopalavras-numa-pagina-mas-tambem-coisasque-se-fazem-entrevista-com-n>. Acedido em 12 de novembro de 2018, às 10 h50min.

NASCIMENTO, Abdias. O Genocídio do Negro Brasileiro: Processo de um Racismo Mascarado. São Paulo: Perspectiva, 2017.

PAULINO, Rosana. Atlântico Vermelho é o mar tingido de sangue pelo tráfico de escravos. In: Folha de Sala da Exposição "Atlântico Vermelho", no Padrão dos Descobrimentos. A Exposição ficou aberta ao público no período de 14 de outubro a 30 de dezembro de 2017.

PAULINO, Rosana. Entrevista com Rosana Paulino. In: Revista do Centro de Pesquisa e Formação / $N^{0}$ 5, setembro 2017. pp. 232-235. Disponível em: <https://www. sescsp.org.br/online/artigo/11557_ ENTREVISTA+COM+ROSANA+PAULINO>.Acedido em 11 de novembro de 2018, às 22h37min.

PAULINO, Rosana. "Atlântico Vermelho I Rosana Paulino" - Exposição no Padrão dos Descobrimentos - Filme Memória-Futura. ProduçãoparaEGEAC/PadrãodosDescobrimentos - 2017; Imagem: João Vaz; Som: António Santos; Direção de Conteúdo: Rita Henriques; Edição: Ricardo Mesquita | Teresa F. Blanc; Pós-Produção: Ricardo Mesquita. Disponível em: <https://vimeo. com/252096733>. Acedido em 11 de novembro de 2018, às $17 \mathrm{~h} 40 \mathrm{~min}$.

RIBEIRO, Djamila. Quem tem Medo do Feminismo Negro? $1^{\text {a }}$ ed. São Paulo: Companhia das Letras, 2018.

SANTOS, Milton. Ser negro no Brasil hoje: Ética enviesada da sociedade branca desvia enfrentamento do problema negro. In: Folha de São Paulo, 07 de maio de 2000. Disponível em: <https://edisciplinas.usp.br/pluginfile. php/772221/mod_resource/content/1/
Se.pdf>. Acedido em 11 de novembro de 2018, às 22h17min.

SELECT: ARTE E CUTLURA CONTEMPORÂNEA. A História das Exposições É A Nova História da Arte? Edição de Aniversário 7 anos. Set/Out/ Nov/2018. pp.38-42

SILA, Abdulai. Kangalutas. Ku Si Mon Editora LDA e Abdulai Sila. Guiné Bissau, 2018.

\section{SOBRE A AUTORA}

Luzia Gomes Ferreira é poeta; Feminista Negra; Docente do Curso de Museologia da Faculdade de Artes Visuais (FAV) do Instituto de Ciências da Arte (ICA) da Universidade Federal do Pará (UFPA). Atualmente coordena o «Grupo de Estudos em Museologia Teórica» (GEMUT) no Laboratório de Pesquisas Integradas em Museologia (LAPIM) e o Projeto de Pesquisa «Dessacralizando a Branquitude Epistemológica: onde estão as/ os não-brancas/os na Teoria Museológica?»O referido Projeto de Pesquisa possue a PORTARIA N) 090/2018 ICA/UFPA e foi contemplado pelo Edital PRODOUTOR 07/2018 da Pró Reitoria de Pesquisa e Pós-Graduação (PROPESP/UFPA) no Subprograma Apoio ao/a Recém Doutor/a - PARD e conta com uma Bolsa de Iniciação Científica, tendo como Discente Pesquisador Pedro Ícaro David Maciel.

E-mail: lu.ayeomi@gmail.com 